\title{
Türkiye Kentsel Katı Atık Kompozisyonunun Kayma Mukavemeti Özellikleri ve Şev Duraylıı̆̆ğın İncelenmesi
}

\author{
Hasan Furat PULAT ${ }^{1}$ \\ Yeliz YÜKSELEN AKSOY ${ }^{2}$
}

\section{ÖZ}

Gelişen dünya nüfusuna paralel olarak kentsel katı atık miktarı her geçen gün artmaktadır. Mühendislik özellikleri iyi tanımlanmamış katı atıklar ile yapılan kontrolsüz depolamalar sonucu oluşan göçmeler can güvenliğini tehlikeye atmakta ve büyük ekonomik kayıplara neden olmaktadır. Bu çalışmada laboratuvar koşullarında belirli kompozisyonlarda sentetik olarak üretilmiş ve doğal atık depolama sahasından alınmış taze ve yıllanmış kentsel katı atık (KKA) numunelerinin doğal su içeriği, organik madde miktarı, özgül ağırlık ve pH değerleri belirlenmiştir. Doğal ve sentetik KKA numunelerinin kayma mukavemeti parametreleri büyük ölçekli direk kesme cihazıyla belirlenmiştir. Elde edilen mühendislik parametreleri kullanılarak mevcut ve tasarlanmış KKA şevlerinin duraylılık analizleri yapılarak statik ve dinamik koşullar altında güvenlik sayıları belirlenmiştir. Çalışmadan elde edilen Türkiye KKA kompozisyonuna ait mühendislik parametreleri ve duraylilık analizleri sonuçları kullanılarak, Türkiye'de daha güvenli ve ekonomik KKA depolama sahalarının tasarımı yapılabilir.

Anahtar Kelimeler: Türkiye kentsel katı atık kompozisyonu, kayma mukavemeti, yıllanma, kompozisyon, duraylılık.

\begin{abstract}
Investigation of Shear Strength and Slope Stability of Turkish Municipal Solid Waste Composition

In parallel with the developing world population, the amount of urban solid waste increases day by day. Uncontrolled storage of solid wastes with poorly defined engineering properties can result in a risk of life safety and serious economic loss. In this study, natural water content, organic matter content, specific gravity and $\mathrm{pH}$ values of the synthetic waste (with pre-determined compositions) and natural waste samples were investigated in laboratory conditions. Shear strength parameters of the synthetic and natural municipal solid waste (MSW) samples were determined by using a large scale direct shear test
\end{abstract}

Not: Bu yaz1

- $\quad$ Yayın Kurulu'na 27.03.2015 günü ulaşmıştır.

- 31 Mart 2017 gününe kadar tartışmaya açıktır.

1 Katip Çelebi Üniversitesi, İnşaat Mühendisliği Bölümü, İzmir - hfirat.pulat@ikc.edu.tr

2 Dokuz Eylül Üniversitesi, İnşaat Mühendisliği Bölümü, İzmir - yeliz.yukselen@deu.edu.tr 
Türkiye Kentsel Katı Atık Kompozisyonunun Kayma Mukavemeti ...

system. The slope stability analyses were conducted for present slopes at static and dynamic conditions and the factor of safety values were obtained. The obtained Turkey MSW composition engineering parameters can be used in the design of safe and economical MSW storage areas in Turkey.

Keywords: Municipal solid waste, shear strength, ageing, composition, slope stability.

\section{GíRiş}

İnsan yaşamının kaçınılmaz bir ürünü olan katı atıkların miktarı, gelişen dünyaya paralel olarak hızla artmaktadır. Kentsel katı atık (KKA)'ların hacimlerinin en aza indirilmesi, düzenli bir şekilde depolanması ve teknolojinin elverdiği ölçüde geri dönüşümlerinin yapılması gerekmektedir. Depolama tesislerinin temel mühendislik malzemesi kentsel katı atıkların bizzat kendisidir. Ancak diğer mühendislik malzemelerine kıyasla kentsel katı atıkların belirgin mühendislik özelliklerinden bahsetmek zordur. Yapısında çok farklı özelliklerde materyalleri bulunduran KKA'lar heterojen yapıda olup, zaman, konum ve çevre şartlarına bağlı olarak, birim hacim ağırlık (b.h.a.), su içeriği, kayma dayanımı, hidrolik iletkenlik ve sıkışabilirlik gibi mühendislik parametreleri zaman içerisinde değişiklik gösterebilmektedir [1]. Katı atık depolama sahalarının yer seçimi tüm dünyada problem yaratmaktadır ve bu durum katı atık depolanması için ayrılan alanların önemini daha da arttırmaktadır. Bu nedenle katı atık sahalarında, daha dik açılar ile daha büyük yüksekliklerde depolama yapılarak daha büyük miktarlarda katı atığın muhafaza edilmesi gerekmektedir. Bu durumlar değerlendirildiğinde, katı atıkların bertarafı için kullanılan depolama sahalarının olabildiğince titiz, detaylı bir şekilde tasarlanması ve uzun yıllar hizmet verebilmesi gereklidir. Bu nedenle ülkeden ülkeye hatta şehirden şehire değişen kompozisyonlara sahip, özellikleri zamanla değişen katı atıkların mühendislik özelliklerinin belirlenmesi güvenli ve ekonomik kentsel katı atık sahalarının oluşturulması açısından son derece önemlidir. Ülkemizdeki KKA'ların mühendislik özellikleri ile ilgili sınırlı sayıda çalışma gerçekleştirilmiştir. Türkiye İstatistik Kurumu (TÜIK) verilerinde 2010 yllı toplam kentsel katı atık miktarı 25.28 milyon ton/yıl olarak rapor edilmiştir [2]. Kişi başına düşen günlük atık ortalaması ise $1.15 \mathrm{~kg} /$ gün olarak hesaplanmıştır. Ülke nüfusu toplamının $\% 82$ 'si, belediye nüfusunun ise $\% 99$ 'u atık toplama hizmetinden yararlanmaktadır. Belediyelerden toplanan atığın \%54.4'ü atık yönetimi mevzuatına uygun yöntemlerle düzenli depolama tesislerinde depolanmakta ve $\% 0.8$ 'i kompostlaştırılmaktadır. Geri kalan \%48.8'lik kısım düzensiz (kontrolsüz) depolama yöntemiyle uzaklaştırılmaktadır. Daha güvenli ve ekonomi açısından daha efektif KKA depo sahalarının ülkemizde tasarlanmasında Türkiye KKA kompozisyonuna uygun mühendislik parametrelerinin kullanılması gereklidir. Fakat katı atık depoları tasarımında KKA özelliklerine uygun parametrelerin seçiminde problemler yaşanmaktadır. Bu çalışmada ülkemizde geliştirilen KKA projelerinde kullanılabilecek Türkiye KKA kompozisyonuna ait bazı mühendislik parametrelerinin belirlenmesine çalışılmıştır.

\subsection{Kentsel Katı Atıkların Kayma Dayanımı}

Doğal olarak ya da sonradan oluşmuş bir şev yapısının duraylılığını etkileyen en önemli faktörlerden biri şevi oluşturan materyalin sahip olduğu kayma mukavemetidir. Kentsel katı 
atıkların kayma mukavemeti parametrelerinin çok geniş bir aralıkta değer aldığı literatürde rapor edilmektedir $[1,3,4,5]$. KKA'ların kayma mukavemetinin bu denli geniş bir aralıkta değer almasının birçok nedeni bulunmaktadır. Bu nedenlerden en önemlisi, içerisinde farklı özelliklere sahip ve değişik kompozisyonlarda birçok materyal bulundurmasıdır. Kentsel katı atıklar yapılarında plastik, kağıt ve tekstil gibi şerit halinde güçlendirici etki yapan lifli malzemeler bulundurabilmektedir. Bu güçlendirici etki normal gerilmelerin etkisi altında oluşan bağlayıcı dirençler (bonding resistance) ve malzemenin lifli özelliğinden kaynaklanan çekme gerilmeleri (tensile strength) olmak üzere iki ana bileşenden oluşmaktadır [6,7]. Zeminlerin kayma davranışından farklı şekilde daneler arası sürtünme kuvvetlerine ek olarak kayma yüzeyindeki şerit halindeki malzemelerin çekme dayanımları da kayma mukavemeti üzerinde etkili olmaktadır. Kentsel katı atıkların kayma mekanizması dört aşamaya ayrılmıştır [6]. Birinci aşamada, deformasyon sırasında sadece sürtünme kuvvetleri artı̧s göstermektedir. İkinci aşamada, artan deformasyonla birlikte zemin davranışından farklı olarak liflerde gerilme oluşarak çekme kuvvetleri ortaya çıkmaktadır. Bunu takiben üçüncü aşamada, lifli malzemelerin çekme dayanımları aşılır, bunun sonucunda yapılarında kayma ve kopmalar meydana gelir. Bu aşamada kentsel katı atıklar maksimum kayma gerilme değerine ulaşır. Son olarak dördüncü aşamada azalan kayma gerilmesi değeri sadece sürtünme kuvvetlerinden meydana gelmektedir.

Literatürde KKA'ların kayma dayanımları üzerinde yapılan çalışmalar genel olarak laboratuvar ve arazi ortamında yapılan çalışmalar olmak üzere ikiye ayrılmaktadır. Kanada'nın farklı atık sahalarından alınan doğal numuneler üzerinde yapılan büyük ölçekli direk kesme deneyleri sonucunda içsel sürtünme açısı değerleri $24^{\circ}$ ile $42^{\circ}$ arasında değer alırken, kohezyon değerleri 10 ile $23 \mathrm{kPa}$ arasında değişiklik göstermiştir [8]. Blackfoot ve Burbank bölgelerinden alınan yıllanmış atıklar ile yapılan deneylerde ise içsel sürtünme açıları $38^{\circ}$ ile $42^{\circ}$ arasında, kohezyon değerleri 16 ile $19 \mathrm{kPa}$ arasında değerler almıştır. $\mathrm{Bu}$ çalışmada kayma mukavemeti parametrelerindeki düşüşün nedeni atıkların bir yıl boyunca ayrışmasıyla ilişkilendirilmiştir. Lifli ve şerit halindeki atıkların (kağıt, karton, tekstil, plastik) kayma dayanımını arttrıcı etkileri olduğu yapılan çalışmalar sonucunda belirlenmiştir [6, 7]. Lifli malzemelerin ürettikleri çekme gerilmeleri ile kayma mukavemetini arttırıcı, KKA yapısını güçlendirici (reinforcement) etki yaptıklarını rapor edilmiştir [6,9]. Taze atıklar için içsel çekme gerilmeleri açısı $35^{\circ}$, ayrışmış KKA'lar için $14^{\circ}$ ve son olarak lif bulundurmayan numuneler için $0^{\circ}$ olarak belirlenmiştir [9]. Büyük boyutlu kesme sistemi kullanılarak yapılan deneyler sonucunda içsel sürtünme açısı değerlerinin $24^{\circ}$ ile $41^{\circ}$ arasında, kohezyon değerlerinin 0 ile $23 \mathrm{kPa}$ arasında olduğu [10] tarafından rapor edilmiştir. Şekil 1'de KKA'ların kayma mukavemeti parametrelerinin küçük ölçekli laboratuvar çalışmalarından tarafından derlenen verileri bir arada gösterilmektedir [11]. Daha önce gerçekleştirilen çalışmalar sonucunda KKA'lara ait kohezyon değerinin 0 ile $50 \mathrm{kPa}$ aralığında, içsel sürtünme açısının $27^{\circ}$ ile $41^{\circ}$ arasında değer alabileceği literatürdeki çalışmalar sonucunda rapor edilmiştir $[3,4,8,10,12]$.

Kentsel katı atık depolama sahalarında muhafaza edilen atıklar yıllanma sonucu, biyolojik ve kimyasal degradasyon nedeniyle fiziksel değişikliklere uğrarlar. Bu değişimler KKA numunelerinin su içeriği, organik madde miktarı, birim hacim ağılık, dane boyu dağılımı, içsel sürtünme açısı ve kohezyon gibi mühendislik parametrelerinde önemli değişiklikler meydana getirmektedir. Degradasyon sonucu lifli ve şerit halindeki atıklar yapısındaki bozunmalar nedeniyle güçlendirme etkilerini yitirmektedirler. Taze atıkların içsel sürtünme açısının yıllanmış atıklardan daha düşük değere sahip olduğunu öne sürülmüştür [6]. Ayrıca 
Türkiye Kentsel Katı Atık Kompozisyonunun Kayma Mukavemeti ...

zamanla kentsel katı atıkların dayanımındaki artışın birim hacim ağırlığa bağlı olarak değisştiği rapor edilmiştir [13]. Zaman içerisinde birim hacim ağılıktaki artış nedeniyle katı atık iskeletinin daha sıkı ve kuvvetli bir yapıya dönüştüğü, buna karşın lifli malzemelerin yapısının bozulduğu belirtilmiştir. KKA numunelerinin 3,5 ve 15 yıllık numunelerinin kayma dayanımlarını incelediğinde, içsel sürtünme açısı değerlerinin sırasıyla $40^{\circ}-38^{\circ}$ den $35^{\circ}-32^{\circ}$ seviyelerine daha sonra $26^{\circ}$ ye indiği rapor edilmiştir [14]. Kohezyon değeri de 50$40 \mathrm{kPa}$ değerlerinden sırasıyla $15-12 \mathrm{kPa}$ ve son olarakta $10 \mathrm{kPa}$ değerine düşüş yapmıştır.

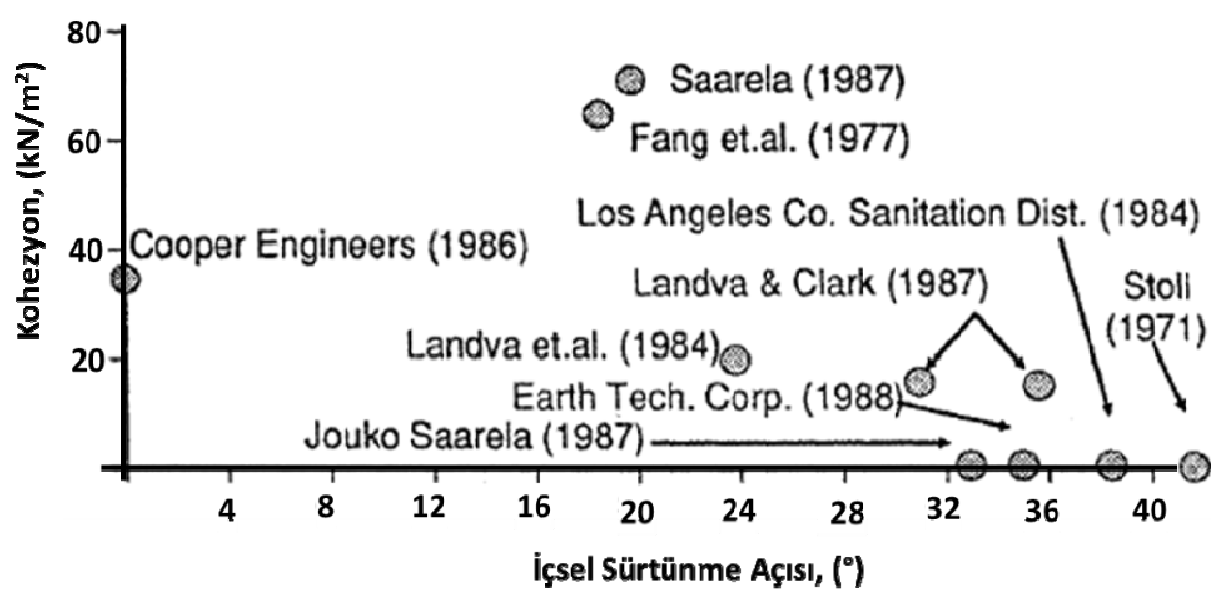

Şekil 1. Kentsel katı atıkların rapor edilmiş kayma mukavemeti değerleri [11]

\subsection{Kentsel Katı Atıkların Şev Duraylıı̆̆ı}

KKA'ların kayma mukavemeti, atık sahalarının maksimum depolama yüksekliklerinin ve şev açılarının belirlenmesi açısından büyük önem arz etmektedir. Dünya genelinde atık sahalarında kontrolsüz yükleme, aşırı yağış, oluşan yangınlar, tahliye sistemlerinin bulunmaması, yeterli sıkıştırma işlemlerinin yapılmaması, olması gerekenden daha dik açıda depolama yapılması gibi nedenlerden dolayı şev göçmeleri meydana gelmektedir. Meydana gelen bu olaylar çok sayıda can kaybına ve büyük maddi kayıplara neden olabilmektedir. Atık depolama sahasının duraylılığı, bir tesisin tasarımında göz önünde bulundurulması gereken en önemli özelliklerden birisidir. Şev duraylılığ analizleri dayanımını yitirip göçmeyle sonuçlanmış atıklara ait mühendislik özellikleri kullanılarak da yapılabilir. Şev duraylılığ analizlerinde klasik kayma poligonu metodunu kullanan araştırmacılar en elverişsiz kayma dairesinin şevin topuk bölgesinden geçtiğini belirlemişlerdir [15]. Atık şevine ait en düşük güvenlik sayısının ise atıkların su içeriğinin arttığı durumlarda oluştuğu belirtilmiştir [16].

$\mathrm{Bu}$ çalışma kapsamında Türkiye KKA kompozisyonuna ait sentetik ve doğal numunelerin mühendislik özellikleri incelenmiştir. Bu amaçla Türkiye KKA kompozisyonuna ait sentetik ve Manisa doğal KKA numuneleri ile yapılan laboratuvar çalışmalarında KKA'ların birim hacim ağırlık, doğal su içeriği, organik madde miktarı, özgül ağırlık ve pH 
değer aralıkları belirlenmiştir. Sentetik olarak üretilen ve büyük plastik tanklar içerisinde dış ortama bırakılarak yıllandırılan KKA numunelerinin mühendislik parametrelerinde meydana gelen değişiklikler incelenmiştir. KKA'ların kayma mukavemeti davranışı büyük ölçekli kesme deneyleri ile belirlenmiştir. Sentetik numuneler için yapılan tüm laboratuvar çalışmaları Manisa ili vahşi katı atık depolama sahasından temin edilen doğal katı atık numuneleri ile de gerçekleştirilmiştir. KKA numuneleri ile gerçekleştiren deney sonuçlarından elde edilen parametreler kullanılarak duraylılık analizleri yapılmıştır. Bu sayede mevcut ve tasarlanmış şev modellerinin, güvenli şev açıları ve güvenlik sayıları belirlenmiş̧ir.

\section{MALZEME VE YÖNTEM}

\subsection{Malzeme Karakterizasyonu}

Bu çalışmada kullanılan Türkiye kentsel katı atık numuneleri laboratuvar ortamında belirli yüzdelerde hazırlanan sentetik kentsel katı atık numunesi Türkiye Sentetik (T-S) ve katı atık depolama sahasından alınan Manisa Doğal (M-D) numunesi olarak iki ana gruba ayrılmaktadır. Türkiye sentetik kompozisyonunun oluşturulmasında KKA kompozisyonu içerisinde en çok karşılaşılan 11 farklı malzeme kullanılmıştır (Kağıt, karton, plastik, metal, ahşap, cam, park-bahçe atığı, mutfak atığı, zemin, kül ve tekstil). Bu çalışmada kullanılan Türkiye kentsel katı atık kompozisyonunu temsil eden Türkiye Sentetik (T-S) KKA numunesine ait değerler Çevre ve Orman Bakanlığı'na ait raporlar [17], Türkiye İstatistik Kurumu verileri ve akademik çalışmalardan derlenmiştir [18, 19]. Çizelge 1'de Türkiye için belirlenen ortalama kentsel katı atık kompozsiyonuna ait değerler gösterilmektedir.

Laboratuvarda hazırlanan sentetik numuneler taze (günlük) Türkiye-Sentetik-Taze (T-S-T) ve biyolojik bozunma ve kimyasal çürümenin ilerlediği ve doğal dokusunu büyük ölçüde yitirdiği Türkiye-Sentetik-Yıllanmış (T-S-Y) KKA numunelerinden oluşmaktadır. Hazırlanan sentetik atık numuneler büyük plastik tanklar içerisinde açık hava ortamında yıllanmaya (12 ay) bırakılmıştır. Açık ortamdaki numuneler depolama tesislerindeki doğal atıklara benzer şekilde tüm atmosferik etkilere açık durumdadır (sıcak-soğuk, kar, yağmur, güneş vb). Kış mevsiminde yağış miktarının çok artması nedeniyle tankların suyla dolup taşmasını önlemek amacıyla plastik tankların alt bölümlerine ince tahliye delikleri açılmıştır. Çalışmada kullanılacak olan doğal kentsel katı atıklar, Manisa ili Şahindere

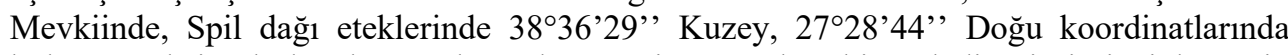
bulunan vahşi atık depolama sahasından Manisa Büyük Şehir Belediyesi’nin izniyle temin edilmiştir. Manisa vahşi atık depolama sahasının kontrolsüz depolama yüksekliği bölgeden bölgeye 30 ile $40 \mathrm{~m}$ arasında değişiklik göstermektedir. Sahada yapılan ölçümlerde $40^{\circ}$ $50^{\circ}$ lik şev eğimleri belirlenmiştir. Şekil 2 'de depolama sahası ve sahaya transferi yapılan doğal atıklar görülmektedir. Katı atık depo sahasından alınan numuneler Manisa-DoğalTaze (M-D-T) ve Manisa-Doğal-Yıllanmış (M-D-Y) numuneler olmak üzere ikiye ayrılmaktadır. Laboratuvar deneylerinde standartlarda belirlenmiş dane boyutu sınırlamalarına uyulması amacıyla açıklığ $50 \mathrm{~mm}$ x $50 \mathrm{~mm}$ olacak şekilde imal edilen büyük ölçekli elekler kullanılarak deneylerde kullanılması uygun olmayan dane boyutları bertaraf edilmiştir. Alınan numuneler nemini kaybetmeyecek şekilde poşetlenip ağızları kapatılarak laboratuvara getirilmişlerdir. Vahşi atık depolama sahasından alınan atık numunelerinin kompozisyon değerleri Manisa Belediyesi 2010 yllı faaliyet raporundan elde edilmiştir. 
Türkiye Kentsel Katı Atık Kompozisyonunun Kayma Mukavemeti ...

Manisa ili KKA kompozisyon yüzdeleri ile Türkiye genel KKA kompozisyon yüzde değerleri genel olarak benzerlik göstermektedir [20].

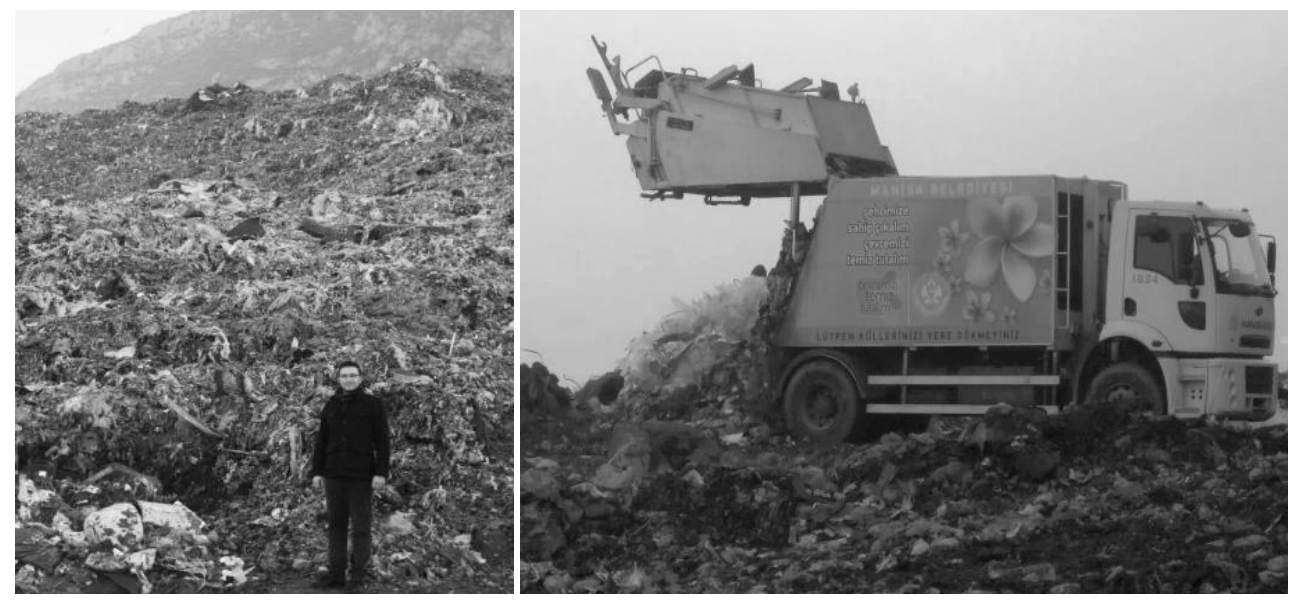

Şekil 2. Manisa ili vahşi katı atık depolama sahası

Manisa KKA kompozisyonunun yaklaşık \%50'sini organik atıklar oluşturmaktadır. Bölgenin sahip olduğu büyük kömür madeni kaynaklarının bir sonucu olarak kül atık kompozisyon içerisinde büyük bir yüzdeye sahiptir.

\subsection{Yöntem}

Sentetik KKA kompozisyonlarını oluşturan materyallerin dane boyutlarında maksimum dane boyutu sınırlaması yapılmıștır. Zemin danelerinin granülometrik analizlerinde kullanılan elek setleri yardımıyla malzemeler belirlenen eleklerden elenmiş elek üstü daneler bertaraf edilmiş̧ir. Çalışma kapsamında tekstil parçacıkları 1'"(25.4 mm), kağıt ve karton parçacıkları 1/2" (12.5 mm), krom metal talaşları 1/4" $(6.3 \mathrm{~mm})$, mutfak atığı, bahçe atığı ve plastik parçacıkları No.4 $(4.75 \mathrm{~mm})$, cam kırıkları ve ağaç talaşı No.10 (2 $\mathrm{mm})$ ve kül daneleri No.40 $(0.425 \mathrm{~mm})$ 'lik eleklerden elenmiştir. Kullanılan malzemeler arasında en büyük dane boyutu, oldukça esnek ve kolay deforme olabilen tekstil parçalarına aittir.

Çalışma kapsamında kullanılan 10 farklı materyalin özgül ağırlık değerleri [21] standardına uygun olarak vakum uygulanarak belirlenmiş̧tir. Literatürde karşıllaşılan KKA özgül ağırlık değerlerinin, bu çalışma için hesaplanmış değerlere oldukça yakın olduğu görülmüştür. Doğal atık depolama sahasından alınmış taze, yıllanmış ve laboratuvarda sentetik olarak üretilmiş üç farklı KKA numunesi üzerindeki yapılan çalışmada doğal taze, doğal yıllanmış ve sentetik numunelerin özgül ağırlık değerleri sırasıyla 0.85-0.97-1.09 olarak rapor edilmiştir [22]. Laboratuvarda hazırlanmış sentetik Amerika Birleşik Devletleri KKA örneği için ise özgül ağırlık değeri 1.60 olarak rapor edilmiştir [23]. Çalışmada kullanılan 11 farklı malzemenin ayrı ayrı ve KKA 
numunelerinin doğal su içerikleri [24] standart test metoduna bağlı olarak belirlenmiştir. Numuneler $65^{\circ} \mathrm{C}$ ve $105^{\circ} \mathrm{C}$ sabit sicaklıklarda kurumaya birakıldığında elde edilen su içeriği arasındaki farklar \%1-2 arasında, organik madde içeriğindeki fark ise \%1'den az olmaktadır. Elde edilen değerler arasında kayda değer bir farklılık olmadığından numuneler 24 saat süresince $105^{\circ} \mathrm{C}$ sabit sıcaklıkta kurumaya bırakılarak su içeriği değerleri elde edilmiştir. KKA numunelerinin organik madde (OM) miktarları [25] test standardına uygun olarak 24 saat $105^{\circ} \mathrm{C}$ sabit sicaklıkta kurutulduktan sonra numuneler porselen potalar içerisinde $440^{\circ} \mathrm{C}^{\prime}$ de yüksek 1 sılı firında 24 saat süresince yakılmış ve OM içerikleri belirlenmiştir. KKA numunelerinin pH değerleri ise [26]'nın önerdiği yöntem ile belirlenmiş̧ir.

KKA numunelerini oluşturan malzemeler çok geniş bir dane dağılımı aralığına sahip olduğu için deney standartları incelendiğinde zemin mekaniği laboratuvarlarında bulunan küçük ölçekli direk kesme cihazlarının, KKA numuneleri üzerinde kullanılmasının doğru sonuçlar vermeyebileceği belirlenmiştir ( $D_{\text {Hücre }} \geq 10 . D_{\text {maks.dane, }}$ ) [27]. Bu nedenle zemin numunelerine oranla çok daha büyük daneler bulunduran KKA numunelerinin kayma mukavemeti değerlerinin belirlenmesi için yüksek kapasiteli tam otomatik büyük ölçekli direk kesme cihazı (TC-S001-01) özel olarak imal ettirilmiştir. Kesme kutusu $300 \mathrm{~mm}$ boyutunda kare kesitli olup $\left(900 \mathrm{~cm}^{2}\right)$ net yüksekliği $150 \mathrm{~mm}$ 'dir. Yatay ve düşey yönde elektronik deplasman ölçerler (transducer) ve yükleme hücreleri verileri otomatik olarak bilgisayara göndermektedir. Yapılan literatür çalışmaları sonucunda KKA numunelerin sıkı zemin numunelerine benzer şekilde pik (maksimum değer noktası) bir kayma gerilmesi değerinin olmadığı belirlenmiştir. Bu nedenle maksimum yanal deformasyon değeri \%20 olarak $(60 \mathrm{~mm})$ seçilmiştir. Deneyler sırasında kullanılacak kesme hızı [26]'da belirtilen konsolidasyon hızına $\left(\mathrm{t}_{9_{0}}\right)$ bağlı hesaplanarak ortalama $3 \mathrm{~mm} /$ dakika olarak belirlenmiştir. Vahşi ve düzenli depolama sahalarındaki KKA'ların birim hacim ağırlıkları geçirmiş oldukları süreçlere (sıkıştırma, üzerini örtme, ufalama v.b) de bağlı olarak çok geniş bir aralıkta değer almaktadır. Bu çalışma kapsamında tüm numunelerin üniform koşullarda test edilebilmesi için numuneler literatürde "iyi sıkıştırılmış" sınıf aralığındaki 9 - 13 $\mathrm{kN} / \mathrm{m}^{3}$ 'lük birim hacim aralık değer aralığında hazırlanmıştır $[10,13,20]$. Türkiye kompozisyonuna ait KKA numunesinin Modifiye Proctor deneyleri sonucunda optimum su içeriği değeri \%73 olarak belirlenmiştir [20]. Doğal su içeriğinde (\%62) laboratuvar ortamında sentetik olarak üretilen Türkiye-Sentetik-Taze numunesine optimum su içeriğine (\%73) gelmesi için gerekli olan su miktarı eklenmiştir. Numunenin olabildiğince homojen hale gelmesi ve eklenen suyun tüm atık malzemelere nüfuz edebilmesi için karıştırılmıştır. Direk kesme deneylerinde numuneler beş eşit katman halinde ve her bir katmana Standart Proctor tokmağı ile 100 darbe vurularak yerleştirilmiştir. $\mathrm{Bu}$ sayede tüm deney numunelerine aynı sıkıştırma enerjisi uygulanmıştır. Yerleştirme ve sıkıştırma işlemi tamamlandığında kullanılan numune miktarı kesme kutusu hacmine bölünerek içerideki numunenin birim hacim ağırlık değeri hesaplanmış ve istenilen değer aralığının sağlanıp sağlanmadığı kontrol edilmiştir. Yapılan hesaplamalar sonucunda Türkiye-Sentetik-Taze numunelerinin deney başındaki başlangıç birim hacim ağırlıkları yaklaşık olarak 10-11 $\mathrm{kN} / \mathrm{m}^{3}$ olarak belirlenmiştir. Deney $3 \mathrm{~mm} /$ dakikalık kesme hızı ile deney dış haznesinin içinde suyun olmadığı durumda ve tamamen su dolu durumda (doygun) ayrı ayrı gerçekleştirilmiştir. Direk kesme deneyleri 49, 98 ve $196 \mathrm{kPa}$ olmak üzere üç farklı normal gerilme değeri için gerçekleştirilmiştir. 
Türkiye Kentsel Katı Atık Kompozisyonunun Kayma Mukavemeti ...

$\mathrm{Bu}$ çalışma kapsamında farklı birim hacim ağırlıklarda ve geometrik özelliklerdeki Türkiye-Sentetik ve Manisa-Doğal numunelerinin taze ve yıllanmış halde şev duraylılık analizleri yapılmıştır. Duraylılık analizlerinde sonlu farklar metodunu kullanan FLAC-2D programı kullanılmıştır. Ayrıca Manisa-Doğal-Taze ve Manisa-Doğal-Yıllanmış numunelerinin duraylılık analizleri Talren (V.4) programı kullanılarak gerçekleştirilmiştir. $\mathrm{Bu}$ sayede geleneksel limit denge yöntemi ve sonlu farklar yöntemini kullanan iki farklı metottan elde edilen güvenlik sayıları karşılaştırılmıştır. Yapılan literatür çalışmalarında KKA'ların birim hacim ağırlık değerlerinin 4 ile $16 \mathrm{kN} / \mathrm{m}^{3}$ arasında kaldığı görülmüştür [4, 28]. Sentetik ve doğal KKA numuneleri kullanılarak yapılan deney sonuçlarından birim hacim ağılık değerlerinin 8 ile $13 \mathrm{kN} / \mathrm{m}^{3}$ arasında değişiklik gösterdiği belirlenmiştir. $\mathrm{Bu}$ sonuçlardan yola çıkılarak analizlerde gevşek ve sıkı birim hacim ağırlıktaki KKA durumunu temsil eden iki farklı birim hacim ağırlık değerinin kullanılması uygun görülmüştür $\left(\gamma_{\text {gevşek }}=7 \mathrm{kN} / \mathrm{m}^{3}, \gamma_{\mathrm{sik1}}=14 \mathrm{kN} / \mathrm{m}^{3}\right)$. Analizlerin tümünde Mohr-Coulomb modeli kullanılmış, literatür araştırmaları sonucu elastisite modülü ve Poisson oranı değerleri sırasıyla $10000 \mathrm{kN} / \mathrm{m}^{3}$ ve 0.3 alınmıştır $[1,4]$.

\section{DENEYSEL SONUÇLAR}

\subsection{Kentsel Katı Atıkların Fiziksel ve Kimyasal Özellikleri}

Çalışma kapsamında kullanılan sentetik ve doğal KKA numunelerinin doğal su içeriği, organik madde miktarı, özgül ağırlık ve pH tayini deneyleri gerçekleştirilmiştir. Sentetik KKA numunelerin üretiminde kullanılan 11 farklı malzemenin elde edilen özgül ağıllık değerleri Çizelge 1'de görülmektedir. En büyük özgül ağırlık değeri 7.41 değeri ile metal atığa, en düşük özgül ağırlık değeri ise 0.76 olarak plastik atığa aittir. Çizelge 1 'de atık malzemelerinin kompozisyon içerisindeki hacim ve ağırlı yüzdeleri gösterilmektedir. Çizelge 1'den görüldüğü üzere talaş atığın hacimce yüzde oranı, ağıllıkça yüzde oranının yaklaşık olarak iki katı değer almıştır. Kompozisyonların oluşturulmasında kullanılan diğer atık malzemelerin ağırlık ve hacim yüzdeleri arasında önemli bir farklılık olmadığı belirlenmiştir. Etüvde 24 saat $105^{\circ} \mathrm{C}$ sicaklıkta bekletilerek belirlenen atık malzemelerin doğal su içeriği değerleri Çizelge 1'de görülmektedir.

Türkiye-Sentetik (T-S) numunesinin yüksek oranda organik madde içermesi buna karşlık metal, cam, zemin gibi özgül ağırlığı yüksek malzemelerden düşük oranda içermesi özgül ağırlık değerinin düşük olmasına neden olmuştur. Türkiye-Sentetik-Taze (T-S-T) numunesinin yüksek $\mathrm{pH}$ değerine sahip, bazik özellikte olduğu belirlenmiştir. Bunun nedeni kompozisyon içerisinde yüksek oranda bulunan kül atıktır (Çizelge 2). Organik atıklar diğer atık malzemelere göre daha yüksek su içeriği değerine sahiptirler. Bu durumun bir sonucu olarak, organik atık bakımından zengin Manisa-Doğal-Taze (M-D-T) numunesinin su içeriği değeri, Manisa-Doğal-Yıllanmış numunesine göre daha yüksektir. Türkiye-Sentetik-Yıllanmış (T-S-Y) numunelerinin özelliklerini belirlemeye yönelik yapılan deneyler yağış miktarının yüksek olduğu sonbahar döneminde gerçekleştirilmiş̧tir. $\mathrm{Bu}$ nedenle sentetik yıllanmış numunelerin doğal su içeriği daha yüksek değer almıştır. Türkiye-Sentetik-Yıllanmış (T-S-Y) numunesinin organik madde miktarı 3 ay sonunda $\% 62$ iken, 12 ay sonunda bu değer $\% 52$ oranına gerilemiştir. Henüz dış ortamda yıllandırılmamış numunenin $\mathrm{pH}$ değeri $10.47 \mathrm{iken,} 12$ ay sonunda $\mathrm{pH}$ değeri 9.42 değerine gerilemiştir. 
Hasan Firat PULAT, Yeliz YÜKSELEN AKSOY

Çizelge 1. Türkiye-Sentetik (T-S) numunesini oluşturan malzemelerin özellikleri

\begin{tabular}{|c|c|c|c|c|c|}
\hline \multirow{2}{*}{ Malzeme } & \multicolumn{2}{|c|}{ Kompozisyon oranları } & \multirow{2}{*}{$\begin{array}{l}\text { Su içeriği } \\
(\%)\end{array}$} & \multirow{2}{*}{$\begin{array}{l}\text { Özgül } \\
\text { ağırlık }\end{array}$} & \multirow{2}{*}{$\begin{array}{c}\text { Maksimum } \\
\text { dane çapı } \\
(\mathrm{mm})\end{array}$} \\
\hline & Ağırlık (\%) & Hacim (\%) & & & \\
\hline Mutfak atığg & 22.5 & 24.1 & 620 & 1.32 & 4.75 \\
\hline Cam kırıkları & 4 & 1.8 & 0.1 & 2.41 & 2.00 \\
\hline Park-Bahçe atığ 1 & 22.5 & 24.1 & 468 & 1.05 & 4.75 \\
\hline Plastik parçacıklar & 10 & 15.5 & 0 & 0.76 & 4.75 \\
\hline Ağaç talaşı & 4 & 8.6 & 8 & 0.96 & 2.00 \\
\hline Metal talaşı-tozu & 2 & 0.3 & 0.1 & 7.41 & 6.30 \\
\hline Kül & 15 & 6.3 & 1 & - & 0.425 \\
\hline Kağıt parçacıkları & 12 & 11.8 & 3 & 1.77 & 12.50 \\
\hline Karton parçacıkları & 3 & 2.9 & 2 & 0.95 & 12.50 \\
\hline Tekstil parçacıkları & 5 & 4.7 & 0 & 1.18 & 25.4 \\
\hline
\end{tabular}

Çizelge 2. KKA numunelerinin fiziksel ve kimyasal özellikleri

\begin{tabular}{lcccc}
\hline Numune & $\begin{array}{c}\text { Özgül } \\
\text { ağırlık } \\
(\mathrm{Gs})\end{array}$ & $\begin{array}{c}\text { Doğal su } \\
\text { içeriği } \\
(\%)\end{array}$ & $\begin{array}{c}\text { Organik } \\
\text { madde } \\
\text { miktarı } \\
(\%)\end{array}$ & $\mathrm{pH}$ \\
\hline Türkiye-Sentetik-Taze (T-S-T) & 1.24 & 62 & 65 & 10.5 \\
Türkiye-Sentetik-Yıllanmış (T-S-Y) & - & 114 & 52 & 9.4 \\
Manisa Doğal Taze (M-D-T) & 1.12 & 94 & 61 & - \\
Manisa Doğal Yıllanmış (M-D-Y) & 1.43 & 68 & 41 & - \\
\hline
\end{tabular}

Manisa Büyük Şehir Belediyesi atık depolama sahasından temin edilen doğal taze atıklar (Manisa-Doğal-Taze) depolama sahasında maksimum 5-7 gün kalmış numunelerden oluşurken, depolama sahasının farklı bölgelerinden alınan yıllanmış atıkların (ManisaDoğal-Yıllanmış) depolama süresi 5 yıldan başlayıp 10 yıla kadar ulaşabilmektedir. Manisa-Doğal-Taze numunesinin doğal su içeriği \%94, organik madde miktarı \%61 olarak belirlenmiştir. Manisa-Doğal-Taze numunesinin özgül ağırlık değeri Türkiye-Sentetik-Taze numunesine yakın bir değerde 1.12 olarak bulunmuştur (Çizelge 2). Birbirlerine benzer kompozisyon özelliklerine sahip Manisa-Doğal-Taze numunesiyle, Türkiye ortalama katı atık kompozisyonuna göre hazırlanan Türkiye-Sentetik-Taze numunesi organik madde yüzdesi bakımından birbirine oldukça yakın değerlere sahiptir $\left(\mathrm{OM}_{\mathrm{MDT}}=\% 61, \mathrm{OM}_{\mathrm{TST}}=\right.$ \%65). Manisa-Doğa-Taze ve Manisa-Doğal-Yıllanmış numunelerinin özgül ağırlık değerleri karşılaştırıldığında, yıllanmış numunenin özgül ağırlık değerinin taze numuneden daha büyük olduğu görülmektedir. $\mathrm{Bu}$ durumun oluşmasının nedeni taze numunenin 
Türkiye Kentsel Katı Atık Kompozisyonunun Kayma Mukavemeti ...

içerisinde yüksek oranda bulunan organik atıkların biyolojik bozunmaları sonucu yerini daha yüksek özgül ağırlıklı atıklara bırakmış olmasıdır.

\subsection{Sentetik Kentsel Katı Atıkların Kayma Mukavemeti Özellikleri}

Türkiye KKA kompozisyonuna ait laboratuar ortamında hazırlanmış sentetik numunelerin kayma mukavemeti özelliklerinin belirlenmesi amacıyla büyük ölçekli direk kesme deneyleri gerçekleştirilmiştir. Askıdaki su düzeyi (perched water table)'nin yükselmesi sonucu ya da çok miktarda yağmur alan bölgelerde yüksek permeabiliteli KKA'lar doygun duruma gelebilmektedir. Bu durumun laboratuvar ortamında temsil edilebilmesi için direk kesme kutusunun diş haznesi su ile doldurularak numune doygun durumdayken deneyler gerçekleştirilmiştir. Doğal su içeriğindeki deneylerde ise dış haznede suyun bulunmadığg 1 durumda optimum su içeriğinde numunelerin deneyleri gerçekleştirilmiştir. Deney süresince meydana gelen yanal deformasyonlar ve karşıllk gelen kayma gerilmeleri bilgisayar tarafından kaydedilmiştir. Üç farklı normal gerilme değeri için maksimum kayma gerilme değerleri ile karşlık gelen normal gerilme değerleri Türkiye-Sentetik-Taze numunesi doygun ve optimum su içeriğindeki durum için Şekil 3'de görülmektedir. Optimum su içeriğindeki durumda numunenin efektif içsel sürtünme açıs $21^{\circ}$, efektif kohezyon değeri $50 \mathrm{kPa}$ olarak belirlenirken, doygun durumda ise efektif içsel sürtünme açıs1 $23^{\circ}$, efektif kohezyon değeri $49 \mathrm{kPa}$ olarak belirlenmiştir.

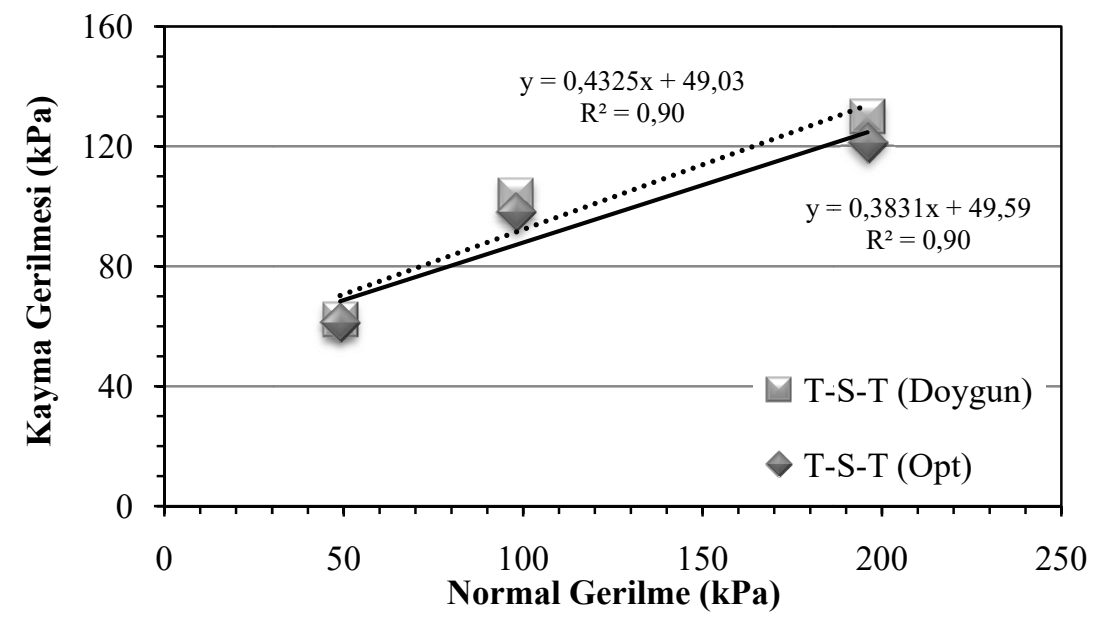

Şekil 3. Doygun ve optimum su içeriğindeki T-S-T numunelerinin kayma gerilmesi-normal gerilme ilişkisi

Askıdaki su seviyesi (perched water table)'nin altındaki durumun temsil edildiği TürkiyeSentetik-Taze doygun numunesine ait içsel sürtünme açısı değerinin Türkiye-Sentetik-Taze optimum numunesine ait değerden $\sim \% 12$ oranında daha yüksek olduğu belirlenmiştir. Aynı kompozisyondaki numunelerin iki farklı deney koşulu altında içsel sürtünme değerleri 
farklılık gösterirken, kohezyon değerlerinin hemen hemen birbirine eşit olduğu belirlenmiştir. Kohezyon ince daneli zeminlerde daneler arasındaki kimyasal ve fiziksel bağ kuvvetlerinden dolayı oluşurken, kentsel katı atıklarda ise kohezyon zeminlerden farklı şekilde daha çok numuneyi meydana getiren bileşenlerin birbirine kenetlenmesi (interlocking) etkisinden meydana gelmektedir [7]. Bu parametre kapilarite kuvvetlerinin neden olduğu zahiri kohezyon şeklinde de tanımlanmaktadır. Her iki numune için de düşey deformasyonlar kayma sırasında 2.4 ile $4.4 \mathrm{~mm}$ arasında değer almıştır ve deney süresince oturma davranışı gözlenmiştir.

Taze olarak üretilmiş sentetik numuneler büyük plastik tanklar içerisinde 12 ay süresince dış ortam koşullarına bırakılarak yıllandırılmış ve kayma mukavemeti parametreleri büyük ölçekli kesme deneyleri ile belirlenmiştir. Türkiye-Sentetik-Yıllanmış numunesi üzerinde yapılan laboratuvar deneylerinde su içeriği $\% 115$, organik madde içeriği $\% 52$ olarak belirlenmiştir. Türkiye-Sentetik-Taze numunesinin organik madde miktarının $\% 65$ olduğu göz önüne alındığında 12 ay süresince organik madde miktarında \%20’lik bir azalma olduğu görülmektedir. Bilgisayar kontrollü direk kesme deneyinden elde edilen kayma gerilmesi - yanal deformasyon ilişkisi Şekil 4'te görülmektedir.

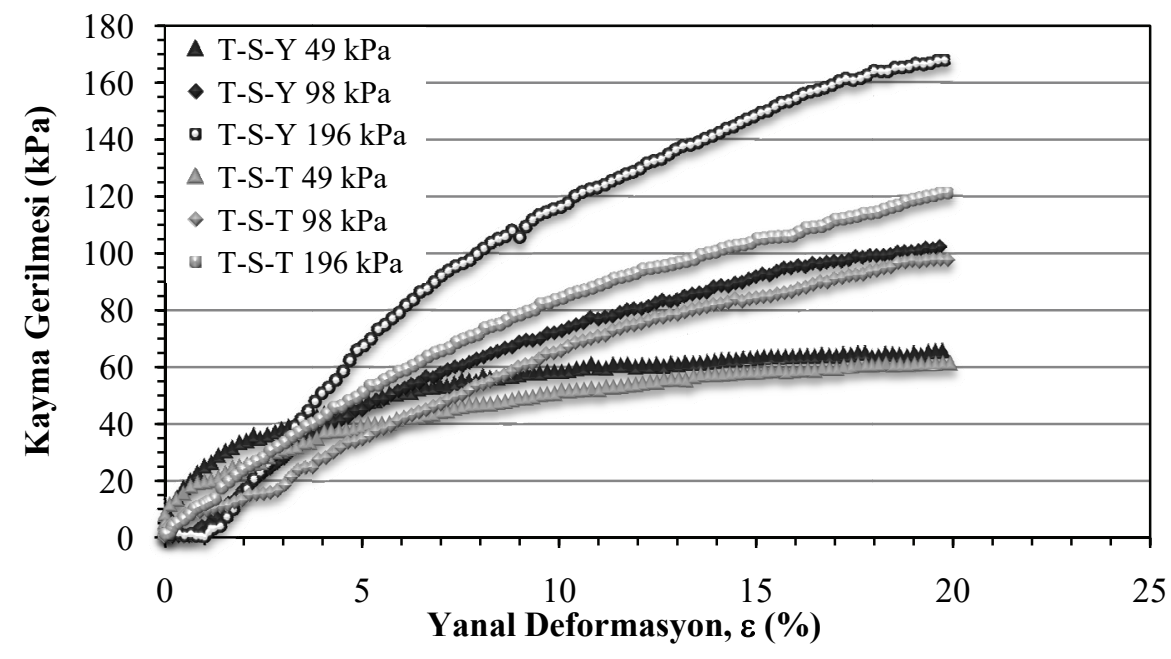

Şekil 4. Türkiye Sentetik Yıllanmış ve Türkiye Sentetik Taze $\tau$ - $\varepsilon$ ilişkisi

Büyük ölçekli direk kesme deneyleri sonucunda Türkiye-Sentetik-Yıllanmış numunesi için efektif içsel sürtünme açısı 35º, efektif kohezyon değeri $33 \mathrm{kPa}$ olarak belirlenmiştir. Türkiye sentetik KKA kompozisyonunun taze ve yıllanmış numunelerinin kayma zarfları karşılaştırmalı olarak Şekil 5 'te gösterilmektedir. Yıllanmış numuneye ait içsel sürtünme açısının taze numuneye oranla çok daha büyük değer aldığı görülmektedir $\left(\varnothing_{\mathrm{T}-\mathrm{S} \text {-Y }}^{\prime}=35^{\circ}\right.$ $>\varnothing^{\prime}{ }_{\text {T-S-T }}=21^{\circ}$ ). Taze numunenin $50 \mathrm{kPa}$ 'lik efektif kohezyon değerine karşılık yıllanmış numunenin kohezyon değerinin $33 \mathrm{kPa}$ olduğu görülmektedir. 
Türkiye Kentsel Katı Atık Kompozisyonunun Kayma Mukavemeti ...

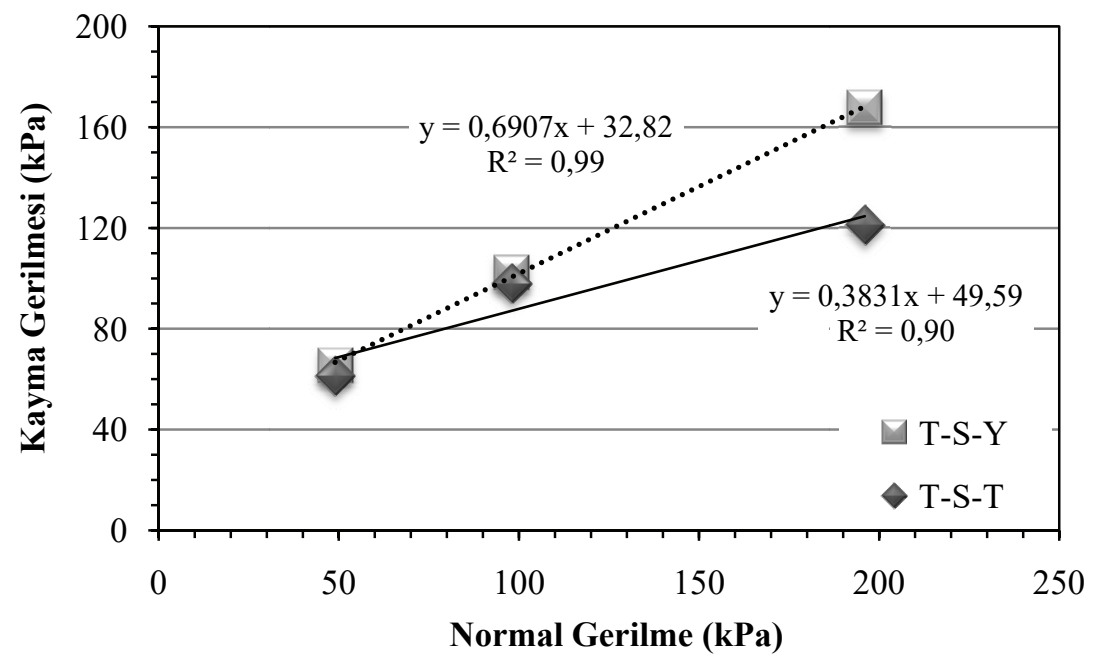

Şekil 5. Türkiye KKA kompozisyonundaki taze ve yıllanmış numunelerin kayma zarfları

Genel olarak elde edilen sonuçlar incelendiğinde, yıllanma etkisi ile içsel sürtünme açısı artarken, kohezyon değerlerinde azalma gözlenmektedir. Bu sonuçlara paralel olarak, taze atıkların içsel sürtünme açılarının yıllanmış atıklardan daha küçük olduğu [6] tarafından da belirlenmiştir. Taze atıklarda güçlendirici etki yapan bileşenlerin (kağıt, karton, plastik, tekstil) yıllanmış numuneye göre daha etkin rol oynadığı belirlenmiştir. Yıllanmaya bağlı olarak kohezyon değerindeki azalmanın nedeni ise kilitlenme etkisi (interlocking) yapan malzemelerin zaman içerisinde özelliklerini yitirmesidir. Elde edilen sonuçlar ışığında zahiri kohezyon değeri üzerinde önemli etkisi olan organik madde miktarının yıllanma sonucu zaman içerisinde azalmasına paralel olarak, kohezyon değerleri de azalmaktadır.

\subsection{Doğal Kentsel Katı Atıkların Kayma Mukavemeti Özellikleri}

Manisa Büyük Şehir Belediyesi vahşi atık depolama sahasından alınan doğal atık numuneler $50 \mathrm{~mm}$ x $50 \mathrm{~mm}$ gözlü eleklerden elenerek, standartlarda belirtilen dane boyu sınırlamalarına uymayan büyük danelerin bertarafı sağlanmıştır. Doğal taze KKA numunesinin büyük ölçekli direk kesme deneyi için sıkıştırma işleminden sonra deney başlangıç birim hacim ağırlığı $11 \mathrm{kN} / \mathrm{m}^{3}$ olarak belirlenmiştir (Şekil 6). Manisa-DoğalTaze (M-D-T) ve Türkiye-Sentetik-Taze (T-S-T) KKA numunelerine ait kayma zarfları Şekil 7'de karşılaştırmalı olarak gösterilmektedir.

Gerçekleştirilen büyük ölçekli direk kesme deneyi sonucunda Manisa-Doğal-Taze (M-DT) numunesinin efektif içsel sürtünme açısı $39^{\circ}$, efektif kohezyon değeri $29 \mathrm{kPa}$ olarak elde edilmiştir. Manisa-Doğal-Taze numunesine ait içsel sürtünme açısı değeri TürkiyeSentetik-Taze numunesine kıyasla çok daha büyük değer almıştır $\left(\varnothing_{\text {M-D-T }}^{\prime}=39^{\circ}>\varnothing_{\text {T-S-T }}^{\prime}\right.$ $\left.=21^{\circ}\right)$. Bu durumun oluşmasında Manisa-Doğal-Taze numunesinin Türkiye-SentetikTaze numunesine kıyasla çok daha büyük dane boyu dağılımına sahip olması rol 
oynamıştır. Doğal ortamdan alınan Manisa-Doğal-Taze numunesi çeşitli ayıklama ve eleme işlemlerinden geçirilmiş olsa da Türkiye-Sentetik-Taze numunesinden daha büyük daneler içermektedir. Manisa ili vahşi atık depolama sahasından alınan doğal yıllanmış Manisa-Doğal-Yıllanmış numunesinin deney başlangıcındaki birim hacim ağırlığ1 12,5 $\mathrm{kN} / \mathrm{m}^{3}$ olarak belirlenmiştir.

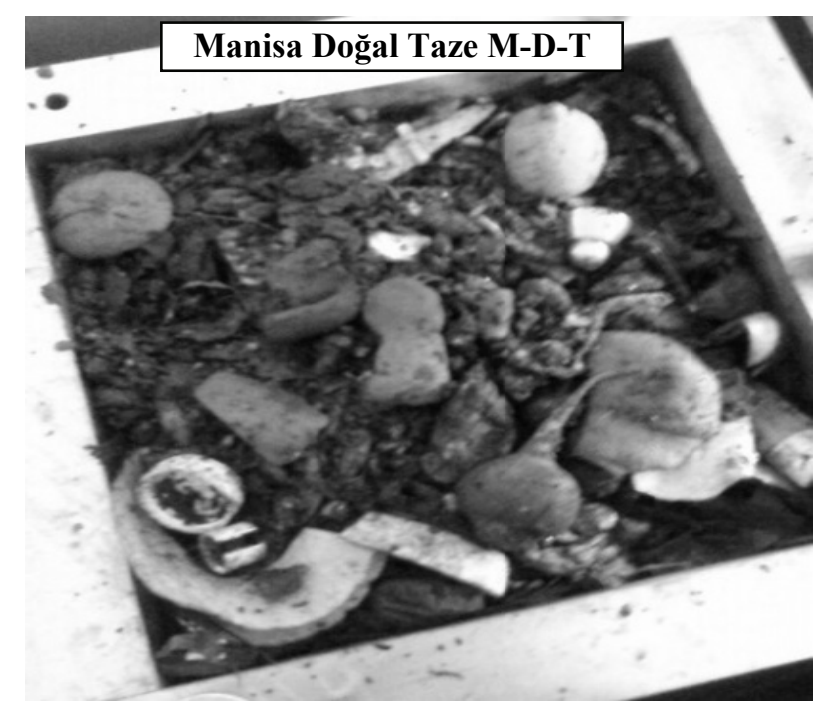

Şekil 6. Kesme kutusu içerisine yerleştirilmiş Manisa-Doğal-Taze (M-D-T) numunesi

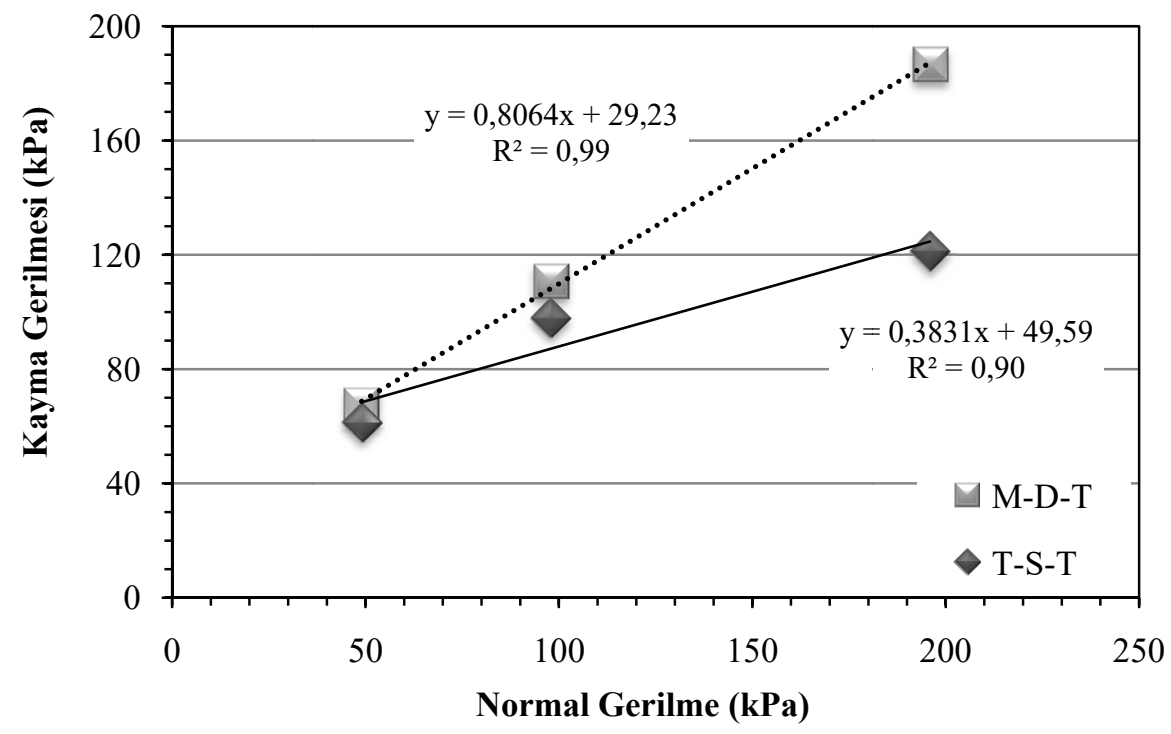

Şekil 7. M-D-T ve T-S-T numunelerinin kayma gerilmesi-normal gerilme ilişkisi 
Türkiye Kentsel Katı Atık Kompozisyonunun Kayma Mukavemeti ...

Manisa Doğal Yıllanmış ve Türkiye Sentetik Yıllanmış numunelerinin kayma gerilmesi yanal deformasyon ilişkisi Şekil 8'de görülmektedir. Manisa-Doğal-Yıllanmış numunesinin efektif içsel sürtünme açısı $38^{\circ}$, efektif kohezyon değeri $40 \mathrm{kPa}$ olarak elde edilmiştir. Benzer kompozisyondaki Türkiye-Sentetik-Ylllanmış numunesi ile Manisa-DoğalYıllanmış numunesinin kayma mukavemeti parametreleri karşılaştıııldığında, taze numunelere kıyasla yıllanmış numunelerin birbirlerine daha yakın değer aldıkları gözlemlenmiştir. Manisa-Doğal-Yıllanmış numunesi, Türkiye-Sentetik-Yıllanmış numunesine kıyasla içsel sürtünme açısında $\% 20$, kohezyon değerinde de $\% 10$ daha büyük değerler elde edilmiştir. $\mathrm{Bu}$ durumun oluşmasında doğal atık numunelerin sentetik numunelere kıyasla daha büyük dane boyu dağılımına sahip olması rol oynamıştır.

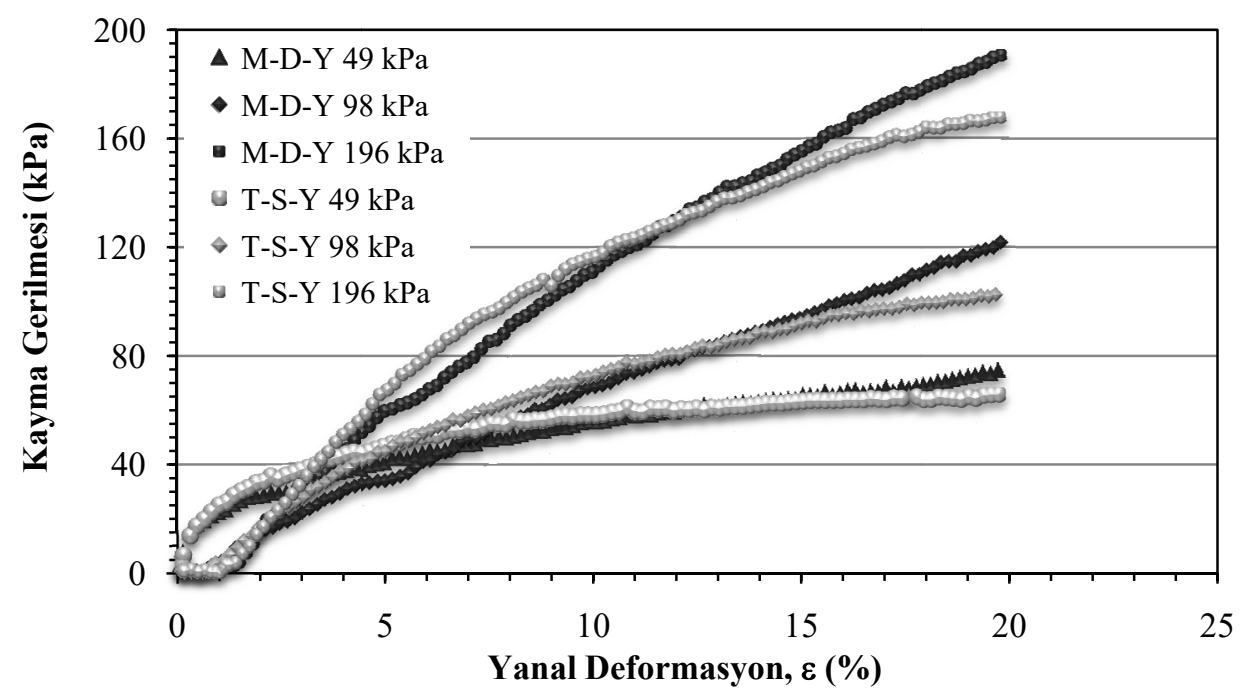

Şekil 8. Manisa Doğal Yıllanmışve Türkiye Sentetik Yıllanmış Taze $\tau$ - $\varepsilon$ iliş̧kisi

Doğal KKA numuneleri kullanılarak yapılan direk kesme deneyleri incelendiğinde, efektif içsel sürtünme açılarının sentetik numunelerden daha büyük değer aldığ görülmektedir. Bunun en büyük nedeni doğal KKA numunelerinin sahip olduğu daha iri danelerden oluşan granülometri özelliğidir. Doğal ve sentetik numunelerin kohezyon değerleri karşılaştığında arada çok büyük bir farklılık gözlenmemiştir. Bu çalışma kapsamında sentetik ve doğal, taze ve yıllanmış KKA numuneler kullanılarak elde edilen büyük ölçekli direk kesme deneyleri sonuçları Çizelge 3 'te özetlenmiştir.

Doğal ve sentetik numunelerin efektif içsel sürtünme açıları karşılaştırıldığında, daha büyük dane dağılımına sahip olan doğal numunelerin daha büyük efektif içsel sürtünme açısına sahip olduğu belirlenmiş̧tir. Sentetik numuneler içerisinde Türkiye-SentetikYıllanmış numunesinin, büyük organik madde içeriğine sahip Türkiye-Sentetik-Taze numunelerinden daha yüksek efektif sürtünme açısı değerine sahip olduğu görülmektedir. 
Hasan Firat PULAT, Yeliz YÜKSELEN AKSOY

Çizelge 3. Çeşitli KKA numunelerinin efektif kayma mukavemeti parametreleri

\begin{tabular}{ccccc}
\hline \hline KKA türü & & Numune & $\boldsymbol{\emptyset}^{\prime}\left({ }^{\circ}\right)$ & $\mathbf{c}^{\prime}\left(\mathbf{k N} / \mathbf{m}^{\mathbf{2}}\right)$ \\
\hline \multirow{3}{*}{ Sentetik } & \multirow{3}{*}{ Taze } & T-S-T (Opt.) & 21 & 50 \\
& & T-S-T (Doy.) & 23 & 49 \\
\cline { 2 - 5 } & Ylllanmış & T-S-Y & 35 & 33 \\
\hline \multirow{2}{*}{ Doğal } & Taze & M-D-T & 39 & 29 \\
\cline { 2 - 5 } & Yillanmış & M-D-Y & 38 & 40 \\
\hline \hline
\end{tabular}

Elde edilen deney sonuçlarının literatürde yapılan diğer çalışmalarla karşılaştııılması Şekil 9'da gösterilmektedir. Çeşitli çalışmalardan elde edilen kayma zarfları ile bu çalışma kapsamında elde edilen kayma zarflarının büyük bir uyum içerisinde olduğu görülmektedir. Grafikteki kalın kesikli çizgiler literatürde karşılaşılan en büyük ve en küçük kayma mukavemeti parametrelerinin sınırların ifade etmektedir.

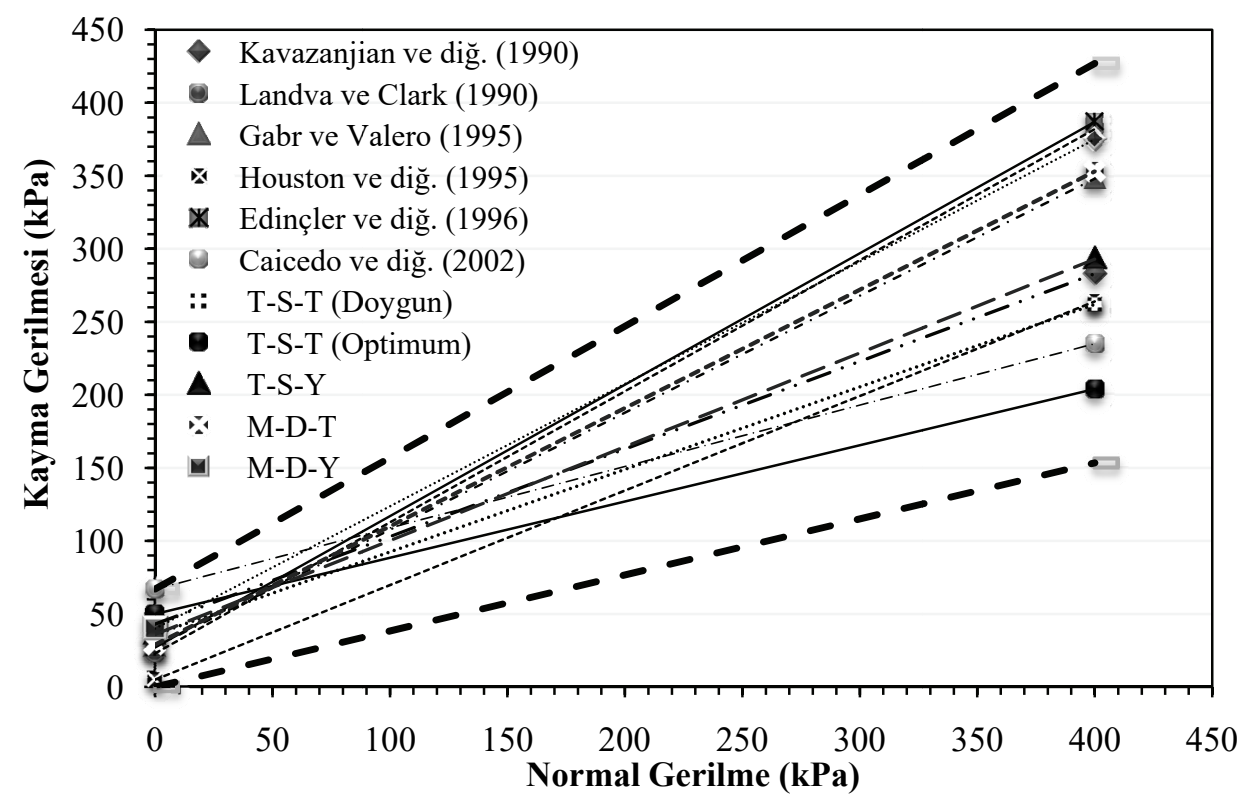

Şekil 9. Çeşitli çalışmaların kayma zarflarının karşılaştırılması

\subsection{Kentsel Katı Atıkların Şev Duraylıık Analizleri}

Duraylılık analizlerinde sonlu farklar metodunu kullanan FLAC (V:7.0.419) programı kullanılmıştır. Yapılan literatür araştırmaları sonucunda KKA depolama sahasında şev eğimlerinin $15^{\circ}$ ile $45^{\circ}$ arasında değiştiği belirlenmiştir [29, 30, 31, 32]. Dünyada bazı vahşi atık depolama sahalarında şev eğiminin olması gerekenden çok daha büyük olduğu belirlenmiş, ancak bunlar çok büyük tehlike yarattığı için analizlerde kullanılmamıştır. 
Türkiye Kentsel Katı Atık Kompozisyonunun Kayma Mukavemeti ...

Gerçekleştirilen duraylılık analizlerinde 1 birim düşey 2 birim yatay $\left(\alpha=26.6^{\circ}\right)$ ve 1 birim düşey 3 birim yatay $\left(\alpha=18.4^{\circ}\right)$ olmak üzere iki farklı şev açısı kullanılmışır. Doğal KKA numuneler ile yapılan çalışmalarda KKA'ların birim hacim ağırlık değerlerinin $4 \mathrm{kN} / \mathrm{m}^{3}$ ile $19 \mathrm{kN} / \mathrm{m}^{3}$ arasında değiştiği görülmektedir. Şüphesiz gerek alt limit gerek ise üst limit normal koşullarda karşılaşılacak birim hacim ağırlık değerlerinin çok uzağında kalmaktadır. Laboratuvar ortamında doğal ve sentetik numuneler ile yapılan deneysel çalışmalarda KKA'ların birim hacim ağırlıklarının $7 \mathrm{kN} / \mathrm{m}^{3}$ ile $14 \mathrm{kN} / \mathrm{m}^{3}$ arasında değiştiği görülmüş ve şev duraylılık analizlerinde bu değerler alt ve üst sınır değerler olarak kullanılmıştır. Duraylılık analizleri değişkenleri olarak iki farklı şev açısı, iki farklı birim hacim ağılık değeri, yıllanma etkisi (taze ve yıllanmış) incelenmiştir. Şev modellerinde yeraltı suyu taban kotunda tanımlanmışıır. Çizelge 4 'te birim hacim ağırlık (b.h.a.), şev açısı, yıllanma etkisi değişsenlerinden yararlanılarak oluşturulmuş modeller ile yapılan analizler sonucu elde edilen güvenlik sayıları gösterilmektedir.

Çizelge 4. Farklı mühendislik parametreleri ile modellenmişs şevlerin güvenlik sayıları

\begin{tabular}{|c|c|c|c|c|c|}
\hline \multirow[t]{2}{*}{ Şev eğimi } & \multirow{2}{*}{$\begin{array}{l}\text { Birim hacim } \\
\text { ağırlık }\left(\mathrm{kN} / \mathrm{m}^{3}\right)\end{array}$} & \multirow[t]{2}{*}{ Kompozisyon } & \multicolumn{2}{|c|}{$\begin{array}{l}\text { Kayma mukavemeti } \\
\text { parametreleri }\end{array}$} & \multirow[t]{2}{*}{ GS } \\
\hline & & & $\phi^{\prime}\left(^{\circ}\right)$ & $\mathrm{c}^{\prime}(\mathrm{kPa})$ & \\
\hline \multirow{4}{*}{$\begin{array}{c}1 \mathrm{~V} / 3 \mathrm{H} \\
\alpha=18,4^{\circ}\end{array}$} & \multirow{2}{*}{7} & T-S-T & 21 & 50 & 4.5 \\
\hline & & T-S-Y & 35 & 33 & 4.9 \\
\hline & \multirow{2}{*}{14} & T-S-T & 21 & 50 & 3.1 \\
\hline & & T-S-Y & 35 & 33 & 3.8 \\
\hline \multirow{4}{*}{$\begin{array}{c}1 \mathrm{~V} / 2 \mathrm{H} \\
\alpha=26,6^{\circ}\end{array}$} & \multirow{2}{*}{7} & $\mathrm{~T}-\mathrm{S}-\mathrm{T}$ & 21 & 50 & 3.8 \\
\hline & & T-S-Y & 35 & 33 & 3.8 \\
\hline & \multirow{2}{*}{14} & T-S-T & 21 & 50 & 2.5 \\
\hline & & T-S-Y & 35 & 33 & 2.8 \\
\hline
\end{tabular}

Çizelge 4'den görüldüğü üzere belirlenen kayma mukavemeti parametreleri, birim hacim ağırlık değerleri ve eğimlerde modellenen şevlerin güvenlik sayıları gerekenden çok daha büyük olarak (overdesign) değerlendirilebilir. Bu durumdan yola çıkılarak aynı kayma mukavemeti parametreleri ve birim hacim ağırlık değerleri ile modellenen şevlerin hangi yükseklik ve hangi eğimde gerekli güvenlik sayısı değerine ( $\mathrm{GS}=1.5)$ ulaştığı incelenmiştir. Türkiye-Sentetik-Taze kompozisyonunun gerekli güvenlik sayısında, iki farklı birim hacim ağırlık değerinde $\left(7 \mathrm{kN} / \mathrm{m}^{3}-14 \mathrm{kN} / \mathrm{m}^{3}\right)$ farklı depolama yüksekliği ve şev açılarında oluşturulmuş modellerinden elde edilen sonuçlar Şekil 10'da gösterilmektedir. Yeraltı su seviyesinin şevin taban kotunda (aktif olmayan) tanımlandığ 1 modellere ek olarak, su seviyesi şev yüzeyi üzerinde tanımlanmış (freatik hat) modellerin de duraylılık analizleri gerçekleştirilmiştir. Yapılan analizler neticesinde şev yüzeyi boyunca tanımlanan freatik hattın duraylılığı olumsuz etkilediği ve güvenlik sayısını \%10-20 oranında düşürdüğü belirlenmiştir. 
Şekil 10'dan görüldüğü üzere $50^{\circ}$ 'lik şev açısında $14 \mathrm{kN} / \mathrm{m}^{3}$ birim hacim ağırlık değeri için yaklaşık depolama yüksekliği $30 \mathrm{~m}$ olurken, $7 \mathrm{kN} / \mathrm{m}^{3}$ birim hacim ağırlık değerinde bu değer yaklaşık 45 m yüksekliğinde olmaktadır. Daha düşük birim hacim ağırlıktaki KKA numunesi aynı şev açılarında büyük birim hacim ağırlıklı numuneden daha büyük yüksekliklerde depolanabilmektedir. Şev açısının duraylılık üzerindeki etkisi incelendiğinde $1 \mathrm{~V} / 2 \mathrm{H}\left(\alpha=26.6^{\circ}\right)$ eğimi verilerek modellenmiş KKA şevinin, $1 \mathrm{~V} / 3 \mathrm{H}$ $\left(\alpha=18.4^{\circ}\right)$ eğimine kıyasla analizlerin tamamında çok daha düşük güvenlik sayılarına sahip olduğu görülmüştür. Şev eğimi arttıkça KKA malzemelerin yüzeyindeki kayma gerilmesi de artış göstereceğinden şev gövdesinin güvenlik sayısı azalmaktadır.

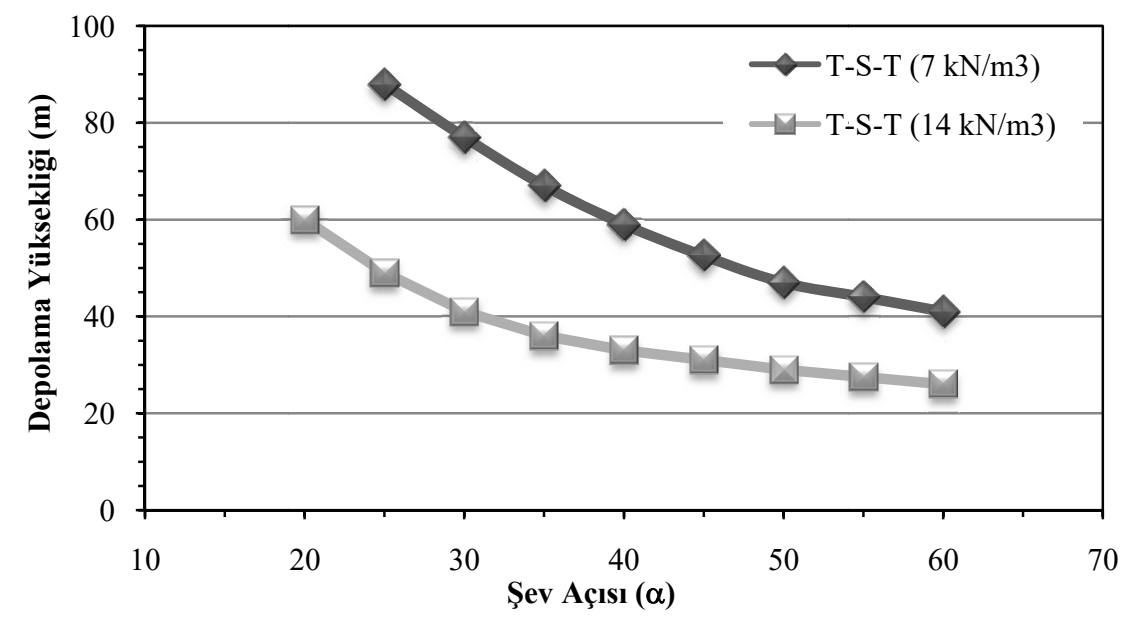

Şekil 10. Kritik güvenlik sayısındaki şev açılarına karşılık gelen depolama yükseklikleri

Duraylılık analizlerinde kullanılan bir diğer önemli değişken KKA'ların birim hacim ağırlığıdır. Birim hacim ağırlık değerleri incelendiğinde, $7 \mathrm{kN} / \mathrm{m}^{3}$ birim hacim ağırlığa sahip numunelerin iki farklı şev eğimi içinde $\left(\alpha=26.6^{\circ}\right.$ ve $\left.\alpha=18.4^{\circ}\right)$ daha yüksek güvenlik sayısı değerlerine sahip olduğu belirlenmiştir. Şev gövdesi içerisindeki gerilmeler malzemelerin kendi ağırlığından kaynaklandığından, şev gövdesinin ağırlığı ne kadar artarsa şev duraylılığı o oranda azalmakta, güvenlik sayısı küçülmektedir. Düzenli atık depolama sahalarının uzun süre hizmet verebilmesi ve ekonomik olabilmesi için olabildiğince büyük hacimlerdeki atığı muhafaza edebilmesi istenmektedir. Bu nedenle depolama yüksekliklerinin olabildiğince yüksek olması istenilmektedir. Ancak yapılan analizlerde depolama yüksekliği ile şev güvenlik sayısının ters orantılı olduğu yani depolama yüksekliği arttıkça şev güvenlik sayısının azaldığı belirlenmiştir.

Manisa iline ait katı atık depolama sahasının geometrik özellikleri çekilen fotoğraflar kullanılarak belirlenmiştir. Manisa vahşi katı atık depolama sahasına ait taze ve yıllanmış numunelerin duraylılık analizleri belirlenen üç farklı şev eğimi $\left(40^{\circ}-45^{\circ}-50^{\circ}\right)$ ve 40 m'lik depolama yüksekliği için gerçekleştirilmiştir. Doğal atık şevlerin duraylılık analizleri sonlu farklar metodunu kullanan FLAC-2D programına ek olarak, limit denge (Bishop ve 
Türkiye Kentsel Katı Atık Kompozisyonunun Kayma Mukavemeti ...

Fellenius) metodlarını kullanan Talren (V.4) programlarıla gerçekleştirilmiş ve karşılaştırmalı olarak güvenlik sayıları elde edilmiştir. İki farklı analiz programı kullanılarak taze ve yıllanmış Manisa doğal KKA numuneleri için elde edilen güvenlik sayıları Çizelge 5'te görülmektedir.

Çizelge 5. Manisa vahşi katı atık depolama sahasının duraylılık analizi sonuçları

\begin{tabular}{|c|c|c|c|c|c|c|}
\hline \multirow{3}{*}{$\begin{array}{c}\text { Şev } \\
\text { Açıs1 }\end{array}$} & \multirow{2}{*}{\multicolumn{2}{|c|}{ FLAC 2-D }} & \multicolumn{4}{|c|}{ TALREN } \\
\hline & & & \multicolumn{2}{|c|}{ Fellenius } & \multicolumn{2}{|c|}{ Bishop } \\
\hline & Taze & Yıllanmış & Taze & Yillanmış & Taze & Y1llanmış \\
\hline$\alpha=40^{\circ}$ & 1.7 & 1.9 & 1.5 & 1.6 & 1.7 & 1.8 \\
\hline$\alpha=45^{\circ}$ & 1.5 & 1.7 & 1.4 & 1.5 & 1.5 & 1.6 \\
\hline$\alpha=50^{\circ}$ & 1.3 & 1.5 & 1.2 & 1.4 & 1.3 & 1.4 \\
\hline
\end{tabular}

Çizelge 5'ten görüldüğü üzere gerçekleştirilen analiz sonuçarından yıllanmış numunelere ait güvenlik sayılarının taze numunelere ait güvenlik sayılarından \%10-\%15 oranında daha büyük değer aldığ 1 belirlenmiştir. Manisa doğal KKA numunelerinin statik durumdaki duraylılık analizlerine ek olarak aynı geometrik ve malzeme özelliklerine sahip modellerin dinamik kuvvetler etkisi altındaki davranışı da incelenmiştir. Başbakanlık Afet ve Acil Durum Yönetimi Başkanlığı Deprem Dairesi Başkanlığı tarafından yönetilen kuvvetli yer hareketleri gözlem ağı sitesinden ilgili bölgeye ait sismik veriler elde edilmiștir (http://kyh.deprem.gov.tr/). Deprem büyüklüğü 5.5 ile 8.0 arasında olan 1976 yılından günümüze kadarki veriler araştırılmış ve 11 deprem kaydı elde edilmiştir. Bu kayıtlar fayın karakteristiği, depremin büyüklüğü, atık depolama sahasına mesafesi, ivme kayıtlarının temizliğine göre tek tek incelenmiş ve 16 Aralık 1977 yllında 38.41 Kuzey - 27.19 Güney episentırında, yüzeyden $24 \mathrm{~km}$ derinde gerçekleşen 5.3 büyüklüğündeki Bornova depremi analizlerde kullanılmak üzere seçilmiştir. Deprem süresi 9.31 saniye, sismografın veri kayıt sıklığ 1 (sampling interval) 0.005 saniye olarak belirtilmiştir. Elde edilen deprem ivme kayıtları maksimum ivme değerleri $0.4 \mathrm{~g}-0.2 \mathrm{~g}-0.1 \mathrm{~g}$ ve $0.05 \mathrm{~g}$ olacak şekilde ölçeklendirilmiştir. Dört farklı maksimum ivme değeri modellenen taban kayasına tanımlanmış, deplasman olarak girilmiş ve şev gövdesinde oluşan maksimum deplasmanlar elde edilmiştir. İlk iki ivme değerinde $(0.4 \mathrm{~g}$ ve $0.2 \mathrm{~g})$ sirasıly $59 \mathrm{~mm}$ ve $11 \mathrm{~mm}$ 'lik deplasmanlar oluşurken diğer iki ivmeye ait deplasmanlar oldukça küçük değer almıştır $(\Delta \mathrm{D}<1 \mathrm{~mm})$.

\section{SONUÇLAR VE ÖNERILLER}

$\mathrm{Bu}$ çalı̧̧ma kapsamında Türkiye kompozisyonuna ait doğal ve sentetik kentsel katı atık numunelerinin geoteknik karakterizasyonu laboratuvar deneyleriyle belirlenmiş, elde edilen mühendislik parametreleri kullanılarak mevcut ve tasarlanmış şev modellerinin duraylılık analizleri gerçekleştirilmişsir. 
Farklı özelliklere sahip sentetik ve doğal KKA'ların fiziko-kimyasal özellikleri incelendiğinde; organik madde miktarının yıllanma etkisine bağlı olarak sentetik ve doğal numuneler için geçen zaman içerisinde azaldığı belirlenmiştir. Numunelerin özgül ağırlıkları 1,12 ile 1,43 arasında değer almıştır. Numunelerin doğal su içeriği her ne kadar dış ortam şartlarına (kar, yağmur) bağlıysa da yüksek su ihtiva eden organik atık oranı azaldıkça doğal su içeriği değeri azalmıştır. Ülkenin sahip olduğu büyük kömür madeni rezervlerinin bir sonucu olarak kül atık kompozisyon içerisinde büyük bir yüzdeye sahiptir (\%15) ve bu durum numunelerin $\mathrm{pH}$ değerlerinin bazik özellikte olmasına neden olmuştur $(\mathrm{pH}=9.4-10.5)$.

Türkiye-Sentetik-Taze numunelerinin optimum su içeriği ve doygun durumdaki kayma mukavemeti parametreleri büyük ölçekli direk kesme deneyleri ile incelendiğinde, doygun numunenin daha yüksek $\varnothing^{\prime}$ değerine sahip olduğu belirlenmiştir. Bu duruma KKA'ların yapılarında bulunan kağıt, karton, tekstil, talaş gibi yüksek su emme kapasitesine sahip malzemelerin suyu adsorbe ederek şişmesi ve kayma gerilmelerine karşı ekstra bir gerilme oluşturmasının neden olduğu düşünülmektedir. Yıllanma etkisi ile Türkiye-SentetikYıllanmış numunenin, Türkiye-Sentetik-Taze numunelere kıyasla daha büyük efektif içsel sürtünme açısına ve daha düşük kohezyon değerine sahip olduğu belirlenmiştir. $\mathrm{Bu}$ durum, yıllanma etkisi ile numune içerisindeki yüksek su içerikli organik atık miktarının azalması, güçlendirici etki yapan lifli atık oranının artmasıyla açıklanmışır. Türkiye-Sentetik-Taze numunesi ile Manisa-Doğal-Taze numunesinin kayma mukavemeti parametreleri karşılaştırıldığında; Manisa-Doğal-Taze numunesinin efektif içsel sürtünme açısının daha büyük, kohezyon değerinin ise daha küçük değer aldığ 1 belirlenmiştir. Sentetik ve doğal yıllanmış numuneler için de benzer sonuçlar elde edilmiştir. Doğal numunenin sentetik numuneye kıyasla daha büyük danelere sahip olması daha büyük içsel sürtünme açısına sahip olmasına neden olmuştur.

Farklı mühendislik özelliklerine sahip şev modellerinin duraylılık analizleri sonucunda $1 \mathrm{~V} / 2 \mathrm{H}$ eğimindeki şevlere ait güvenlik sayılarının $1 \mathrm{~V} / 3 \mathrm{H}$ eğimindeki modellerden $\% 15$ $\% 25$ oranında daha küçük değer aldığı belirlenmiştir. Tasarımlarda kullanılan şev güvenlik sayısı esas alınarak (GS=1,5) iki farklı birim hacim ağılıktaki (7 ve $\left.14 \mathrm{kN} / \mathrm{m}^{3}\right)$ TürkiyeSentetik-Taze kompozisyonunun depolama yüksekliği-şev açısı ilişkileri analizlerle etkin ve kullanışlı hale getirilmiştir. Aynı geometri ve geoteknik özellikler ile modellenmiş şevlerin güvenlik sayıları farklı metotlarla analiz yapan FLAC ve Talren programları ile karşılaştırılmış, FLAC programından daha yüksek güvenlik sayıları elde edilmiştir. Manisa doğal KKA numunelerinin statik durumdaki duraylılık analizlerine ek olarak aynı geometrik ve malzeme özelliklerine sahip modellerin dinamik kuvvetler etkisi altındaki davranışı da incelenmiştir. Dört farklı ölçek kullanılarak $(0.4 \mathrm{~g}-0.2 \mathrm{~g}-0.1 \mathrm{~g}$ ve $0.05 \mathrm{~g})$ yapılan analizler sonucunda, ilk iki ivme değerinde $(0.4 \mathrm{~g}$ ve $0.2 \mathrm{~g})$ sirasıyla $59 \mathrm{~mm}$ ve $11 \mathrm{~mm}$ 'lik deplasmanların meydana geldiği belirlenmiştir.

Kentsel katı atıkların kompozisyonu ülkeden ülkeye hatta şehirden şehire değişiklik gösterebilmektedir. $\mathrm{Bu}$ nedenle KKA depo alanları tasarımı yapılırken o alandaki KKA kompozisyonunun parametrelerine göre dizayn yapılması gerekmektedir. Ayrıca su içeriğindeki değişimler ve yıllanma etkisi ile mühendislik parametrelerinde oluşabilecek değişiklikler dizayn kriterlerinde gözönüne alınarak güvenilir ve ekonomik KKA depo alanları inşa edilebilir. 
Türkiye Kentsel Katı Atık Kompozisyonunun Kayma Mukavemeti ...

\section{Semboller}

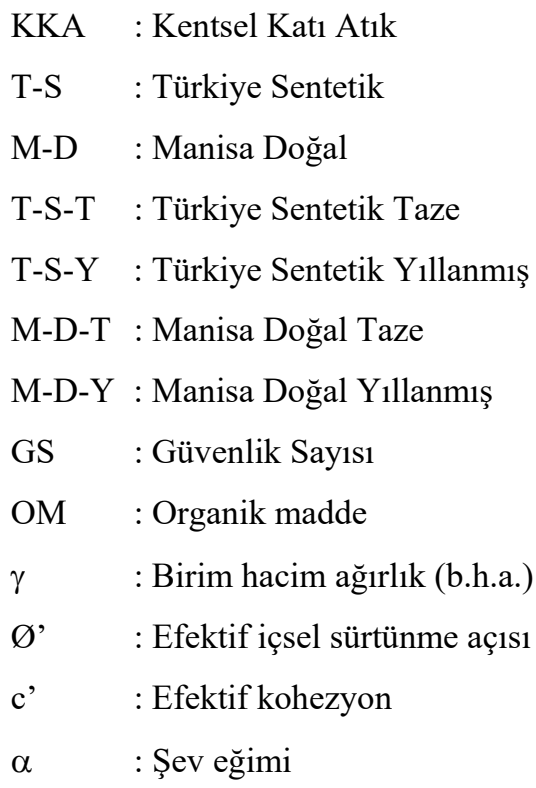

\section{Teşekkür}

$\mathrm{Bu}$ çalışma Celal Bayar Üniversitesi Bilimsel Araştırma Projeleri (BAP 2013-046) tarafindan desteklenmiştir. Destek için teşekkürlerimizi sunarız.

\section{Kaynaklar}

[1] Zekkos, D., Evaluation of Static and Dinamic Properties of Municipal Solid Waste, Ph.D. Thesis, Berkeley, California, 2005.

[2] Türkiye İstatistik Kurumu (TÜIK), Bölgesel İstatistikler, İnternet adresi: www.tuik.gov.tr, 2010.

[3] Mazzucato, A., Simonini, P., Colomo, S., Analysis of Block Slide in a MSW landfill, In: Proceedings Sardinia 99, 7th International Waste Management and Landfill Symposium, Cagliari, Italy, 4-8 October 1999.

[4] Kavazanjian, E., Matasovic, N., Bachus, R.C., Large-diameter Static and Cyclic Laboratory Testing of Municipal Solid Waste, In: Proceedings Sardinia 99, 7th International Waste Management and Landfill Symposium, Cagliari, Italy, 4-8 October 1999.

[5] Zhan, T.L.T., Chen, Y.M., Ling, W.A., Shear Strength Characterization of Municipal Solid Waste at the Suzhou Landfill, China, Eng Geol., 97, 97-111, 2008. 
[6] Kölsch, F., The Influence of Fibrous Constituents on Shear Strength of Municipal Solid Waste, Ph.D. Thesis, Technische Universitat Braunschweig Brauschweig, Germany Leichtweiss-Institut, 1996.

[7] Langer, U., Shear and Compression Behaviour of Undegraded Municipal Solid Waste, Ph,D, Thesis, Loughborough University, England, 2005.

[8] Landva, A.O., Clark, J., Geotechnical Testing of Waste Fill, Proceedings of $39^{\text {th }}$ Canadian Geotechnical Conference, Ottawa, Ontario, 371-385, 1986.

[9] Kölsch, F., Material Values for Some Mechanical Properties of Domestic Waste, Proceedings of the 5th International Landfill Symposiumin Sardinia, Italy, 2-6 October 1995.

[10] Landva, A.O., Clark, J.I., Geotechnics of Waste Fill, Geotechnics of Waste FillsTheory and Practice, ASTM STP 1070, In: Landv A., Knowles D (eds) American Society for Testing and Materials, Philadelphia, Pennsylvania, 86-103, 1990.

[11] Singh, S., Murphy, B., Evaluation of the Stability of Sanitary Landfills, Geotechnics of Waste Landfills - Theory and Practice, Landva, A. and Knowles, G.D., Editors, ASTM Special Publication 1070, Proceedings of Symposium Held in Pittsburgh, Pennsylvania, USA, 240-258, 1990.

[12] Withiam, J,L., Bushell, T.D., Germann, H.W., Prediction and Performance of Municipal Landfill Slope, In: Proceedings of Specialty Conference Geoenvironment 2000, Geotechnical Special Publication 46 (2), 1005-1019, New Orleans, LA, 1995.

[13] Oweis, I.S., Khera, R.P., Geotechnology of Waste Management, Second Edition, Cengage Learning, Butterworths, Kent, England, 1998.

[14] Turczynski, U., Geotechnical Aspects of Building Multicomponent Landfills, Ph.D. Thesis, Bergakademie, Freiberg (Sachsen), Germany, 1988.

[15] Kölsch, F., and Ziehmann, N., Landfill Stability - Risks and Challenges, Waste Management World, Issue: May-June, ISWA, Copenhagen, 2004.

[16] Bogner, J.E., Reddy, K., Spokas, K., Dynamic Water Balance Aspects of Bioreactor Landfills, Proceedings Sardina International Solid and Hazardous Waste Symposium, Calgary, Sardinia, 2001.

[17] ÇOB (T.C. Çevre ve Orman Bakanlığı), 2006, Atıkların Düzenli Depolanmasına Dair Yönetmelik, T,C, Resmi Gazetesi No:27533, Tarih: 26,03,2010.

[18] Aykol, K., Evsel Katı Atıkların Geoteknik Özelliklerinin Modellenmesi, Yüksek lisans tezi, İstanbul Teknik Üniversitesi, Fen Bilimleri Enstitüsü, 2008.

[19] Gören, S., Sanitary Landfill, Forart Matbaası,, İstanbul, 2006.

[20] Pulat, H.F., Kentsel Katı Atıkların Geoteknik Karakterizasyonu ve Duraylılığının İncelenmesi, Doktora Tezi, Celal Bayar Üniversitesi, Fen Bilimleri Enstitüsü, Türkiye, 2014. 
Türkiye Kentsel Katı Atık Kompozisyonunun Kayma Mukavemeti ...

[21] ASTM D854-14, Standard Method of Test for Specific Gravity of Soil Solids by Water Pycnometer, ASTM International, West Conshohocken, PA, 2014.

[22] Babu Sivakumar, G.L, Reddy, K.R, Chouksey S.K., Constitutive Model for Municipal Solid Waste Incorporating Mechanical Creep and BiodegradationInduced Compression, Waste Manag., 30(1), 11-22, 2010.

[23] Reddy, K.R., Hettiarachchi, H., Parakalla, N.S., Gangathulasi, J., Bogner, J.E., Geotechnical Properties of Fresh Municipal Solid Waste at Orchard Hills Landfill, USA, Waste Manag,, 29 (2), 952-959, 2009.

[24] ASTM D2216-10, Standard Test Methods for Laboratory Determination of Water (Moisture) Content of Soil and Rock by Mass, ASTM International, West Conshohocken, PA, 2010.

[25] ASTM-D 2974-14, Standard Test Methods for Moisture, Ash and Organic Matter of Peat and Other Organic Soils, ASTM International, West Conshohocken, PA, 2014.

[26] Kocasoy, G., Atıksu Arıtma Çamuru ve Katı Atık ve Kompost Örneklerinin Analiz Yöntemleri, Boğaziçi Üniversitesi Yayınları, 1994.

[27] ASTM D3080-11, Standard Test Method for Direct Shear Test of Soils Under Consolidated Drained Conditions, ASTM International, West Conshohocken, PA, 2011.

[28] Zekkos, D., Bray, J., Kavazanjian, E., Matasovic, N., Rathje, E., Riemer, M., Unit Weight of Municipal Solid Waste, J, of Geotech, and Geoenvir Engrg. 132(10), 1250-1261, 2006.

[29] Stark, T.D., Eid, H.T., Evans, W.D., Sherry, P.E., Municipal Solid Waste Slope Failure, II: Stability Analyses, J, Geotech, and Geoenvir, Engrg., 126(5), 408-419, 2000.

[30] Kölsch, F., Stability Analysis According to Different Shear Strength Concepts, 2nd International Workshop HPM, Southampton, 2007.

[31] Huvaj-Sarihan, N., Stark, T.D., Back Analyses of Landfill Slope Failures, 6th International Conference on Case Histories in Geotechnical Engineering and Symposium in Honor of Professor James K. Mitchell, 2008.

[32] Kölsch, F., Shear Strength of Waste, Third International Workshop on HydroPhysico-Mechanics of Landfills, Braunschweig, Germany, 10 - 13 March 2009. 